\title{
Root traits for infertile soils
}

\section{Philip J. White ${ }^{1 *}$, Timothy S. George ${ }^{1}$, Lionel X. Dupuy ${ }^{1}$, Alison J. Karley ${ }^{1}$, Tracy A. Valentine ${ }^{1}$, Lea Wiesel ${ }^{1}$ and Jane Wishart ${ }^{2}$}

1 The James Hutton Institute, Invergowrie, UK

2 School of Biology, University of St. Andrews, St. Andrews, UK

\section{Edited by:}

Boris Rewald, University of Natural Resources and Life Sciences,

Austria

Reviewed by:

Jennifer Powers, University of

Minnesota, USA

Moshe Silberbush, Ben-Gurion

University of the Negev, Israel

*Correspondence:

Philip J. White, The James Hutton

Institute, Invergowrie, Dundee

DD2 5DA, UK

e-mail:philip.white@hutton.ac.uk
Crop production is often restricted by the availability of essential mineral elements. For example, the availability of $\mathrm{N}, \mathrm{P}, \mathrm{K}$, and $\mathrm{S}$ limits low-input agriculture, the phytoavailability of $\mathrm{Fe}, \mathrm{Zn}$, and $\mathrm{Cu}$ limits crop production on alkaline and calcareous soils, and $\mathrm{P}, \mathrm{Mo}, \mathrm{Mg}, \mathrm{Ca}$, and $\mathrm{K}$ deficiencies, together with proton, $\mathrm{Al}$ and $\mathrm{Mn}$ toxicities, limit crop production on acid soils. Since essential mineral elements are acquired by the root system, the development of crop genotypes with root traits increasing their acquisition should increase yields on infertile soils. This paper examines root traits likely to improve the acquisition of these elements and observes that, although the efficient acquisition of a particular element requires a specific set of root traits, suites of traits can be identified that benefit the acquisition of a group of mineral elements. Elements can be divided into three Groups based on common trait requirements. Group 1 comprises N, S, K, B, and P. Group 2 comprises $\mathrm{Fe}, \mathrm{Zn}, \mathrm{Cu}, \mathrm{Mn}$, and $\mathrm{Ni}$. Group 3 contains mineral elements that rarely affect crop production. It is argued that breeding for a limited number of distinct root ideotypes, addressing particular combinations of mineral imbalances, should be pursued.

Keywords: root architecture, mineral nutrition, rhizosphere, soil solution, uptake

\section{INTRODUCTION}

Crop production, worldwide, is restricted by the concentrations and chemical forms of mineral elements present in the soil solution (Table 1). Adequate supplies of the essential mineral elements nitrogen $(\mathrm{N})$, potassium $(\mathrm{K})$, phosphorus $(\mathrm{P})$, calcium $(\mathrm{Ca})$, magnesium $(\mathrm{Mg})$, sulphur $(\mathrm{S})$, boron $(\mathrm{B})$, iron $(\mathrm{Fe})$, manganese $(\mathrm{Mn})$, zinc $(\mathrm{Zn})$, copper $(\mathrm{Cu})$, nickel $(\mathrm{Ni})$, molybdenum (Mo), and chlorine $(\mathrm{Cl})$ are required for maximal crop production (White and Brown, 2010). Phytoavailability of N, K, P, or S often limits low-input agriculture (Fageria et al., 2011; Mueller et al., 2012), the phytoavailability of $\mathrm{Fe}, \mathrm{Zn}$, and $\mathrm{Cu}$ limits crop production on alkaline and calcareous soils, which comprise $25-30 \%$ of agricultural land (White and Broadley, 2009), and the phytoavailability of $\mathrm{K}, \mathrm{P}, \mathrm{Mg}, \mathrm{Ca}$, or Mo can limit crop production on acid soils, which comprise $>40 \%$ of agricultural land (von Uexküll and Mutert, 1995; Sumner and Noble, 2003) and additionally suffer from excessive concentrations of protons, aluminium and Mn (Fageria et al., 2011; White and Greenwood, 2013). Since mineral elements are acquired by the root system, it has been suggested that the development of genotypes with appropriate root traits might increase crop yields on infertile soils (White et al., 2005, in press; Lynch, 2007, 2011, in press; Hawkesford, 2011). This paper examines the root traits likely to improve the acquisition of essential mineral elements. It deals with these traits in a general way that is not intended to provide parameter values for sophisticated mathematical models of resource capture (cf. Barber, 1995; Jungk and Claassen, 1997; Dunbabin et al., 2003; Roose and Fowler, 2004; Postma and Lynch, 2012). It is observed that, although efficient acquisition of a particular element requires a specific set of root traits, suites of traits can be identified that benefit the acquisition of several mineral elements. Breeding for a limited number of distinct root ideotypes, benefitting the acquisition of several elements coincidentally, would optimize the use of research resources.

\section{THE PHYTOAVAILABILITY OF ESSENTIAL MINERAL ELEMENTS}

If essential mineral elements are not present in the soil, they must be provided to enable crop production. Various agronomic strategies can be employed to increase the efficiency with which inorganic and organic fertilizers are used. In principle, these optimize the chemistry, quantity, placement, and timing of fertilizer applications (Fageria et al., 2011; Simpson et al., 2011; Mueller et al., 2012; White et al., 2012, in press; White and Greenwood, 2013). These agronomic strategies can be complemented by cultivating genotypes with appropriate root traits. When mineral elements are present in the soil, strategies can be developed to increase their acquisition by roots, thereby improving the mineral nutrition of crops and, ultimately, crop yields (Lynch, 2007, 2011, in press; White and Broadley, 2009; Richardson et al., 2011; White et al., 2012, in press; White and Greenwood, 2013).

Root traits improving the acquisition of essential mineral elements, and tolerance of potentially toxic mineral elements in the soil, have been the focus of many theoretical studies and field, glasshouse and laboratory investigations (White et al., 2005, in press; Lynch, 2007, 2011, in press). The availability of mineral elements for acquisition by roots is determined by (1) interception through root growth, (2) local diffusion in the rhizosphere, and (3) mass flow in the soil solution to the root surface (Table 1; Barber, 1995; Chapin et al., 2002; Fageria et al., 2011). Direct root interception is not considered to be important for the acquisition of mineral elements because the amounts required for 
Table 1 | Physical processes likely to supply essential mineral elements to the root surface of plants growing in the field, and the occurrence of deficiency disorders and mineral toxicity symptoms in agricultural systems.

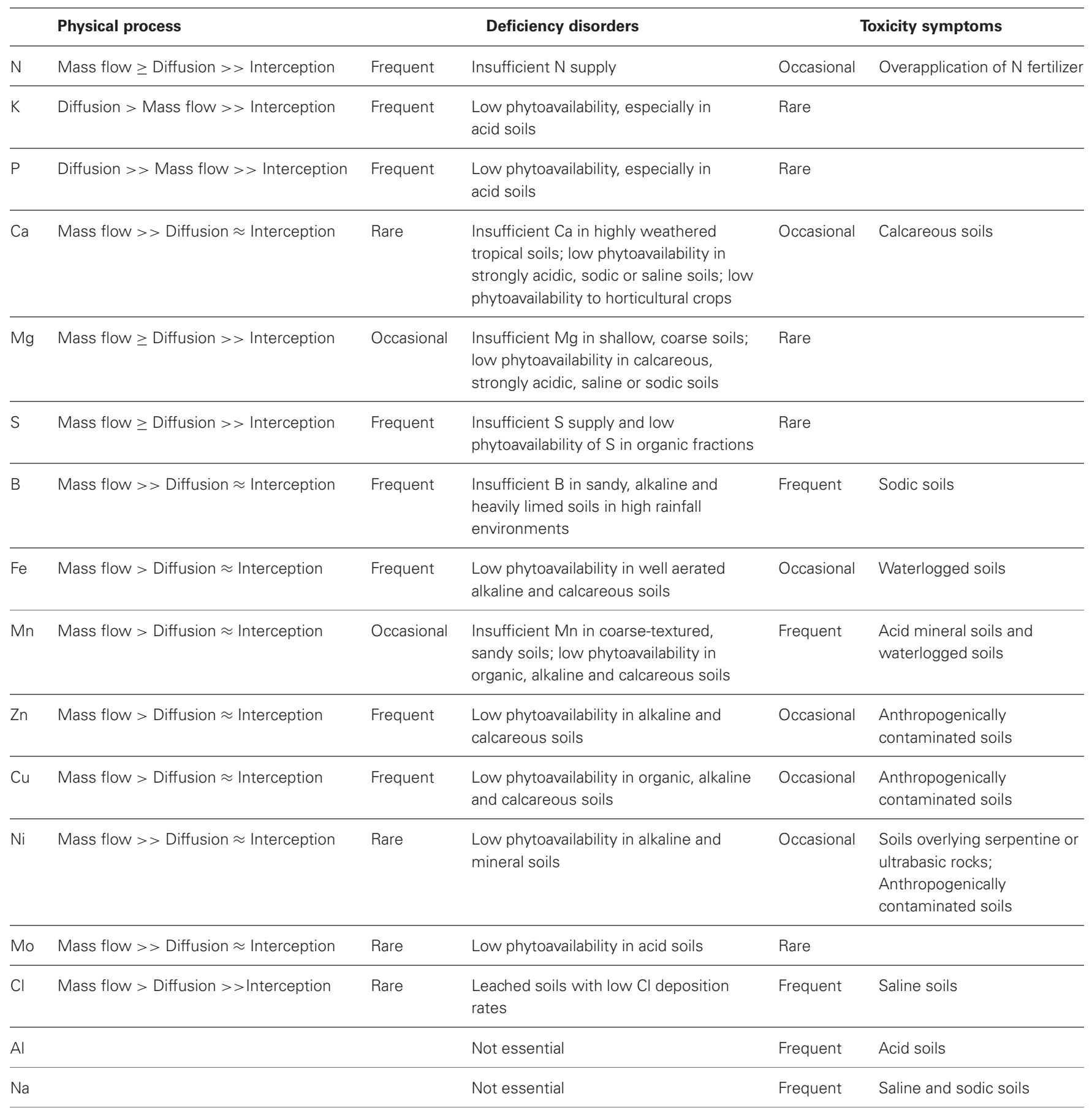

It should be noted that the application of mineral fertilizers and soil amendments, soil type, chemistry and microbiology, and the prevailing environmental conditions will all influence the dominant physical process supplying essential mineral elements to the root surface. References: Barber (1995), White and Broadley (2001,

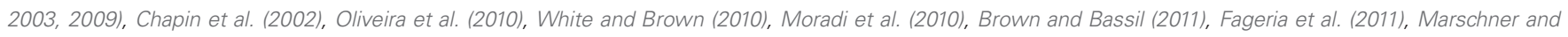
Rengel (2012), White and Greenwood (2013).

plant nutrition are generally far greater than those intercepted. However, root proliferation and elongation are important in exploiting the soil volume, reducing the path length for diffusion and mass flow, and providing an extensive surface area for the uptake of mineral elements. Diffusion of mineral elements is determined by the concentration gradient between the soil solution and the root surface (White and Greenwood, 2013). It operates over short distances, such as the width of the rhizosphere, and 
is especially important for the acquisition of $\mathrm{P}$ and $\mathrm{K}$ (Table $\mathbf{1}$ ). It is facilitated by agricultural practices and crop genotypes that increase the concentrations of mineral elements in the soil solution and high-capacity systems for their uptake by root cells (Lynch, 2011; White, 2013). The mass flow of a mineral element to the root surface is determined by its concentration in the soil solution and the transpiration-driven movement of water to the root (White and Greenwood, 2013). It is important for the acquisition of mineral elements with high concentrations in the soil solution, such as $\mathrm{N}, \mathrm{K}, \mathrm{S}, \mathrm{Ca}, \mathrm{Mg}$ and $\mathrm{Cl}$ in agricultural soils, and for mineral elements that are required in relatively small quantities by plants, such as Fe, Mn, Zn, Cu, Ni, B, and Mo (Table 1).

Root traits influencing the acquisition of mineral elements include: (1) root elongation rate, lateral root production, root hair characteristics, root length density (root length/soil volume) and soil penetration, all of which increase the volume of soil explored by the root system and the surface area for the uptake of mineral elements, (2) the gravitropism of root growth, which influences the ability to exploit different soil horizons, (3) the proliferation of roots in patches of soil containing high concentrations of mineral elements that are immobile in the soil, which reduces the carbon and energy requirement for their acquisition, (4) the turnover of fine roots, which redistributes carbon following the capture of localized resources, (5) specific root length (length/mass quotient) and formation of aerenchyma, which affect the carbon and energy requirement for resource capture by influencing root respiration, (6) high-capacity systems for the uptake of elements whose delivery to the root surface is determined by diffusion in the rhizosphere, (7) modification of rhizosphere $\mathrm{pH}$ and the exudation of organic solutes and enzymes, which affect the concentrations of mineral elements in the soil solution either directly through soil chemistry or indirectly though the culture of appropriate microbial communities, and (8) interactions with microbes either intimately, through mycorrhizal associations or nodulation, or remotely, through the culture of beneficial microbes or exclusion of pathogenic ones in the rhizosphere (Figure 1A).

\section{ROOT IDEOTYPES FOR IMPROVING THE ACQUISITION OF ESSENTIAL MINERAL ELEMENTS}

The acquisition of different mineral elements, and often different chemical forms of mineral elements, requires different root traits (Figure 1A). Nevertheless, suites of traits can be identified that benefit the acquisition of groups of mineral elements (Figure 1B). Since different chemical forms of mineral elements are interconverted in the soil, and crop mineral nutrition requires only the acquisition of an essential mineral element, root traits that benefit the acquisition of an element, rather than a particular chemical form of that element, have been identified. For example, the choice of traits for $\mathrm{N}$ acquisition is predicated on the supposition that nitrate is often the dominant chemical form of $\mathrm{N}$ in agricultural systems, but can be immobilized in the rhizosphere as ammonium, or converted to organic compounds through biological activities. Group 1 comprises elements that are required by crops in large amounts and are often in short supply in low-input agricultural systems. Group 1A comprises elements that are readily soluble and, therefore, can be present at high concentrations in the soil solution and follow the movement of water in the soil profile. This group includes $\mathrm{N}$, when present as nitrate, and $\mathrm{S}$, when present as sulphate, which are both delivered to the root surface primarily by mass flow, and $\mathrm{K}$, which reaches the root surface both by mass flow and diffusion in the rhizosphere. Boron is also included in Group 1A. The only element in Group $1 \mathrm{~B}$ is $\mathrm{P}$, which is required in large quantities by plants, can be present in high amounts in the soil, but reaches the surface of the root primarily by diffusion. Group 2 comprises elements required in smaller amounts by crops that are often present in adequate amounts in soils, but whose phytoavailability is constrained by soil chemical properties, such as high soil $\mathrm{pH}$. This group includes $\mathrm{Fe}, \mathrm{Zn}, \mathrm{Ni}, \mathrm{Mn}$, and $\mathrm{Cu}$. Group 3 comprises elements whose supply rarely limits crop production, namely $\mathrm{Ca}$, $\mathrm{Mg}, \mathrm{Cl}$, and Mo (White and Broadley, 2001, 2003; Brown and Bassil, 2011; White and Greenwood, 2013). Designing root ideotypes for Group 3 elements is not an immediate priority, and is not discussed further.

\section{ROOT IDEOTYPES FOR THE ACQUISITION OF NITROGEN, SULPHUR, POTASSIUM, AND BORON}

The Group 1A root architectural ideotype can be illustrated by the "steep, cheap, and deep" ideotype that facilitates nitrate acquisition, and N-fertilizer use efficiency, in crops (Lynch, in press; White et al., in press). Nitrate is present in high concentrations in the soil solution and follows the movements of water in the soil profile. Deeper roots are considered beneficial for nitrate acquisition and restricting the movement of nitrate to watercourses through leaching (Dunbabin et al., 2003; Lynch, in press; White et al., in press). Nitrate is delivered to plant roots predominantly by mass flow of the soil solution and nitrate acquisition can be accelerated by increasing root length and surface area, and by increasing transpiration (Garnett et al., 2009; Lynch, in press; White et al., in press). Increasing root nitrate uptake capacity can also improve $\mathrm{N}$-acquisition (Lynch, in press). Lynch (in press) has argued that the proliferation of roots in patches of local abundance might be maladaptive for the acquisition of mineral elements that are readily soluble in the soil solution, such as nitrate. However, the proliferation of roots in N-rich patches can improve the acquisition of ammonium $\left(\mathrm{NH}_{4}^{+}\right)$and organic $\mathrm{N}$-compounds (see below). Increasing the abundance of cortical aerenchyma can reduce the carbon and energy costs associated with a large root system (Lynch, in press). Relationships with $\mathrm{N}_{2}$-fixing bacteria, whether symbiotic or associative, can improve the $\mathrm{N}$-nutrition of crops and genotypes of both legumes and non-legumes fostering greater biological $\mathrm{N}_{2}$-fixation often have higher yields in $\mathrm{N}$-limited environments (Kraiser et al., 2011; James and Baldani, 2012; Kumar et al., 2012). The $\mathrm{N}$ nutrition of plants growing on unfertilized soils can also be improved through mycorrhizal associations (Fitter and Moyersoen, 1996; Bennett et al., 2013).

Although nitrate is the form of $\mathrm{N}$ taken up by roots of most crops, they can also take up $\mathrm{NH}_{4}^{+}$, urea, amino acids, and peptides (Miller and Cramer, 2005; Gojon et al., 2009; Kraiser et al., 2011). Ammonium is the main form of $\mathrm{N}$ taken up by plants adapted to acidic and anaerobic soils (Miller and Cramer, 2005). The root architectural ideotype for the acquisition of $\mathrm{NH}_{4}^{+}$, which is relatively immobile in the soil, resembles that for the acquisition 
A

\begin{tabular}{|c|c|c|c|c|c|c|c|c|c|c|c|c|c|c|c|}
\hline Trait & s & $\mathrm{k}$ & B & $\mathbf{P}$ & Fe & M & & & $\mathrm{Mn}$ & $\mathrm{Cu}$ & $\mathrm{Ca}$ & Mg & CI & & \\
\hline Early root vigour I faster growth & 1 & 1 & 1 & 1 & 1 & 1 & 1 & 1 & & 1 & 1 & 0 & 0 & 0 & 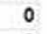 \\
\hline Greater root shoot biom ass quotient & 1 & 1 & 1 & 1 & 1 & 1 & 1 & 1 & & 1 & 1 & 0 & 0 & 0 & 0 \\
\hline More root branching & 1 & 1 & 1 & 1 & 1 & 1 & 1 & 1 & & 1 & 1 & 1 & 0 & 0 & 0 \\
\hline More / longer root hairs & 1 & 1 & 1 & 1 & 1 & 1 & 1 & 1 & & 1 & 1 & 0 & 0 & 0 & 0 \\
\hline Greater root length densty & 1 & 1 & 1 & 1 & 1 & 1 & 1 & 1 & & 1 & 1 & 0 & 0 & 0 & 0 \\
\hline Improved soll penetration & 1 & 0 & 1 & 1 & 0 & 1 & 1 & 1 & & 1 & 1 & 0 & 0 & 0 & 0 \\
\hline Deeper r $\infty$ ts & 1 & 1 & 1 & 1 & 0 & 0 & 0 & 0 & & 1 & 0 & 1 & 1 & 1 & 0 \\
\hline Topsoil foraging (agravitropism) & 0 & 1 & 0 & 0 & 1 & 0 & 1 & 0 & & 1 & 1 & 0 & 0 & 0 & 0 \\
\hline Lower root tumover & 0 & 0 & 0 & 0 & 0 & 0 & 0 & 0 & & 0 & 0 & 1 & 0 & 0 & 0 \\
\hline Root proliferation in organic patches & 1 & 1 & 0 & 0 & 1 & 1 & 1 & 1 & & 1 & 1 & 0 & 0 & 0 & 0 \\
\hline Root proliferation in $\mathrm{N}$-rich patches & 1 & 0 & 0 & 0 & 0 & 0 & 0 & 0 & & 0 & 0 & 0 & 0 & 0 & 0 \\
\hline Root proliferation in Krich patches & 0 & 0 & 1 & 0 & 0 & 0 & 0 & 0 & & 0 & 0 & 0 & 0 & 0 & 0 \\
\hline Root proliferation in P-rich patches & 0 & 0 & 0 & 0 & 1 & 0 & 0 & 0 & & 0 & 0 & 0 & 0 & 0 & 0 \\
\hline Thinner roots & 1 & 1 & 1 & 1 & 1 & 1 & 1 & 1 & & 1 & 1 & 0 & 0 & 0 & 0 \\
\hline More aerenchyma (reduced respiratory load) & 1 & 1 & 1 & 1 & 1 & 1 & 1 & 1 & & 1 & 1 & 0 & 0 & 0 & 0 \\
\hline Greater cell wall CEC & 0 & 0 & 0 & 0 & 0 & 1 & 1 & 1 & & 1 & 1 & 1 & 1 & 0 & 0 \\
\hline Less Caspanan band & 0 & 0 & 0 & 1 & 0 & 1 & 1 & 1 & & 1 & 1 & 1 & 0 & 1 & 0 \\
\hline Greater transpiration & 1 & 1 & 1 & 1 & 0 & 1 & 1 & 1 & & 1 & 1 & 1 & 1 & 1 & 1 \\
\hline Greater $N$ uptake capacity & 1 & 0 & 0 & 0 & 0 & 0 & 0 & 0 & & 0 & 0 & 0 & 0 & 0 & 0 \\
\hline Greater K uptake capacity & 0 & 0 & 1 & 0 & 0 & 0 & 0 & 0 & & 0 & 0 & 0 & 0 & 0 & 0 \\
\hline Greater B uptake capacity & 0 & 0 & 0 & 1 & 0 & 0 & 0 & 0 & & 0 & 0 & 0 & 0 & 0 & 0 \\
\hline Greater $P$ uptake capacity & 0 & 0 & 0 & 0 & 1 & 0 & 0 & 0 & & 0 & 0 & 0 & 0 & 0 & 0 \\
\hline Greater $\mathrm{Fe}^{2 *}$ uptake / PM redox capacity & 0 & 0 & 0 & 0 & 0 & 1 & 0 & 0 & & 0 & 0 & 0 & 0 & 0 & 0 \\
\hline Greater siderophore uptake capacity & 0 & 0 & 0 & 0 & 0 & 1 & 1 & 1 & & 1 & 1 & 0 & 0 & 0 & 0 \\
\hline Secretion of Biological Nitnfication Inhibitor: & 1 & 0 & 0 & 0 & 0 & 0 & 0 & 0 & & 0 & 0 & 0 & 0 & 0 & 0 \\
\hline Greater secretion of mucillage & 1 & 1 & 1 & 0 & 1 & 1 & 1 & 1 & & 1 & 1 & 0 & 0 & 0 & 0 \\
\hline Increased mizosheath & 0 & 1 & 0 & 0 & 1 & 1 & 0 & 0 & & 0 & 0 & 1 & 0 & 0 & 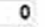 \\
\hline Greater rhizosphere acidification & 0 & 0 & 1 & 1 & 1 & 1 & 1 & 1 & & 1 & 1 & 0 & 1 & 0 & 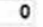 \\
\hline Greater secretion of organic acids & 0 & 1 & 1 & 0 & 1 & 1 & 0 & 1 & & 1 & 1 & 0 & 0 & 0 & 0 \\
\hline Greater secretion of siderophores & 0 & 0 & 0 & 0 & 1 & 1 & 1 & 1 & & 1 & 1 & 0 & 0 & 0 & 0 \\
\hline Greater secretion of phenolics & 0 & 0 & 0 & 0 & 1 & 1 & 0 & 0 & & 0 & 0 & 0 & 0 & 0 & 0 \\
\hline Greater secretion of phosphatases & 0 & 0 & 0 & 0 & 1 & 1 & 1 & 1 & & 1 & 1 & 0 & 0 & 0 & 0 \\
\hline Greater secretion of sulphatases & 0 & 1 & 0 & 0 & 0 & 0 & 0 & 0 & & 0 & 0 & 0 & 0 & 0 & 0 \\
\hline Nodulation & 1 & 0 & 0 & 0 & 0 & 0 & 0 & 0 & & 0 & 0 & 0 & 0 & 0 & 0 \\
\hline Mycorthizal associations & 1 & 1 & 1 & 1 & 1 & 1 & 1 & 1 & & 1 & 1 & 0 & 0 & 0 & 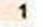 \\
\hline Culturng $\mathrm{N}_{2}$-fixing microbes & 1 & 0 & 0 & 0 & 0 & 0 & 0 & 0 & & 0 & 0 & 0 & 0 & 0 & 0 \\
\hline Culturing $\mathbf{S}$-mineralising microbes & 0 & 1 & 0 & 0 & 0 & 0 & 0 & 0 & & 0 & 0 & 0 & 0 & 0 & \\
\hline Cultuning $P$ solubilising microbes & 0 & 0 & 0 & 0 & 1 & 0 & 0 & 0 & & 0 & 0 & 0 & 0 & 0 & 0 \\
\hline Culturing microbes mobilising micronutrient: & 0 & 0 & 0 & 0 & 0 & 1 & 1 & 1 & & 1 & 1 & 0 & 0 & 0 & 0 \\
\hline Pathogen resistance & 1 & 1 & 1 & 1 & 1 & 1 & 1 & 1 & & 1 & 1 & 1 & 1 & 1 & \\
\hline
\end{tabular}

B

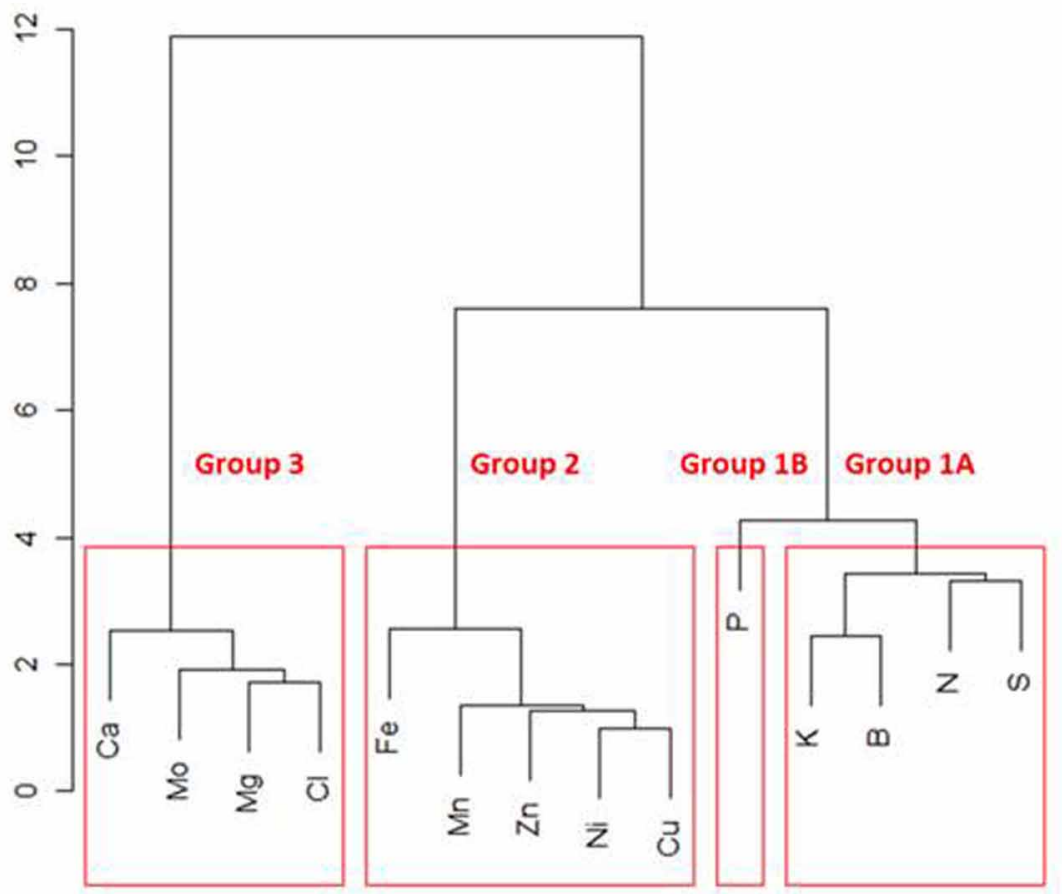

FIGURE 1 | (A) Matrix of root traits likely to improve the acquisition of essential mineral elements. Traits are scored as being likely (1) or unlikely (0) to improve the acquisition of an essential mineral element in reduced-input agricultural systems. (B) Clustering of essential mineral elements requiring similar root traits to improve their acquisition. Relationships were calculated from the data presented in the matrix. 
of $\mathrm{K}^{+}$. This ideotype incorporates high root length densities, which reduce the distance $\mathrm{NH}_{4}^{+}$must diffuse in the rhizosphere to reach the root surface, and the proliferation of roots in $\mathrm{NH}_{4}^{+}$rich patches. Plants releasing inhibitors of biological nitrification into the rhizosphere limit the conversion of $\mathrm{NH}_{4}^{+}$to nitrate and, thereby, retain $\mathrm{N}$ in the vicinity of the root (Subbarao et al., in press). This can improve the efficiency of $\mathrm{N}$-fertilizer use by minimizing nitrate leaching.

Crops take up most of their $S$ as sulphate (De Kok et al., 2011). Effective acquisition of sulphate, which is readily soluble and follows the movement of water in the soil profile, requires similar root architecture to the acquisition of nitrate (White et al., in press). In response to S-deficiency, plants generally increase their capacity for sulphate uptake and alter their root architecture to increase the volume of soil explored at depth, for example by the development of lateral roots close to root apices (López-Bucio et al., 2003; Gojon et al., 2009; De Kok et al., 2011). Increasing transpiration accelerates the delivery of $S$ to the root surface. About $75-90 \%$ of the $S$ in soils is present in the topsoil as organic compounds, and S phytoavailability can be enhanced by secreting enzymes degrading soil organic-S, either from plant roots themselves or from their associated microbial communities (Canfield and Farquhar, 2012; Lamers et al., 2012).

Potassium acquisition can be increased by accelerating $\mathrm{K}^{+}$ delivery to the root surface by increasing mass flow of the soil solution or $\mathrm{K}^{+}$diffusion in the rhizosphere. Although $\mathrm{K}^{+}$concentrations in soil solutions generally lie between 0.1 and $1 \mathrm{mM}$, this is not sufficient to supply a rapidly growing crop with enough $\mathrm{K}$ by mass flow alone. Root traits that improve $\mathrm{K}$ acquisition include: (1) early root vigor and the preferential partitioning of biomass to roots, (2) greater lateral rooting and production of root hairs, increased root length/mass quotient and increased root length density, all of which increase the surface area for $\mathrm{K}^{+}$ uptake by roots and reduce the distance required for $\mathrm{K}^{+}$diffusion and water flow, (3) greater root penetration of strong soils, to improve access to soil resources, (4) the release of organic acids that solubilize "non-exchangeable" $\mathrm{K}$ in soils and increase the $\mathrm{K}^{+}$ concentration in the soil solution, (5) greater $\mathrm{K}^{+}$uptake by root cells, which reduces the $\mathrm{K}^{+}$concentration at the root surface and accelerates the delivery of $\mathrm{K}^{+}$by diffusion, and (6) increasing transpiration, which increases the delivery of $\mathrm{K}^{+}$to the root surface through mass flow of the soil solution (Jungk and Claassen, 1997; Rengel and Damon, 2008; White, 2013).

Boron is also included in Group 1A. Boron deficiency in crops is prevalent across a wide range of climates, cropping systems, and soils (Brown and Bassil, 2011). Like other Group 1A elements, B is readily soluble in water and is delivered to the root surface by mass flow. It is easily leached from soils and its distribution in the soil profile is determined by water movements. Thus, root architectural traits required for efficient $\mathrm{B}$ acquisition resemble those required for the efficient acquisition of $\mathrm{N}, \mathrm{S}$, and $\mathrm{K}$. The phytoavailability of B is restricted in acid and mildly alkaline soils.

\section{ROOT IDEOTYPE FOR PHOSPHORUS ACOUISITION}

A "topsoil foraging" root architectural ideotype has been proposed for the acquisition of $\mathrm{P}$, which is relatively immobile in the soil and concentrated in the topsoil. This ideotype incorporates: (1) early root vigor and the preferential production of roots in the topsoil, (2) greater root branching and the production of long root hairs, (3) high root length density in the topsoil and the proliferation of lateral roots in P-rich patches, (4) greater root length/mass quotient, either through the development of thinner roots or the formation of root aerenchyma, and (5) the partitioning of a greater proportion of plant biomass to the root system (White et al., 2005, in press; Lynch, 2007, 2011; White and Hammond, 2008; Richardson et al., 2011; Brown et al., in press). This architectural ideotype can be complemented by accelerating the diffusion of $\mathrm{P}$ to the root surface by increasing (1) the phosphate uptake capacity of root cells, and (2) the phosphate concentration in the rhizosphere solution through the secretion of protons and organic acids to solubilize P-salts and phytases and phosphatases to degrade organic P-compounds, which can be effected either by roots themselves or through the activities of beneficial microbes (Barea et al., 2005; White and Hammond, 2008; Richardson et al., 2011). Associations with mycorrhizal fungi are also known to improve plant $\mathrm{P}$ nutrition and increase crop yields (Smith and Read, 2008).

\section{ROOT IDEOTYPES FOR ELEMENTS WITH RESTRICTED PHYTOAVAILABILITY IN ALKALINE SOILS}

Topsoil foraging is an appropriate root ideotype for the acquisition $\mathrm{Mn}, \mathrm{Cu}$, and $\mathrm{Ni}$, which are relatively immobile in the soil and concentrated in the topsoil, but not necessarily for $\mathrm{Fe}$ and $\mathrm{Zn}$, which are distributed more evenly and likely to be phytoavailable throughout the soil profile (White and Greenwood, 2013). An even spread of roots throughout the soil is more suitable for the acquisition of $\mathrm{Fe}$ and $\mathrm{Zn}$. Since Fe, $\mathrm{Zn}, \mathrm{Mn}, \mathrm{Cu}$, and $\mathrm{Ni}$ all have restricted mobility in the soil, their acquisition can be improved by investing more biomass in the root system, by developing a more extensive root system, and by proliferating lateral roots in mineral-rich patches (White and Broadley, 2009; White and Greenwood, 2013). Since the delivery of these elements to the root surface is largely determined by mass flow of the soil solution, increasing transpiration will accelerate their acquisition (White and Greenwood, 2013). Root traits increasing the phytoavailability of these elements in the rhizosphere, such as the secretion of protons, phytosiderophores, and organic acids, increases their acquisition by crops (White and Broadley, 2009, 2011; White and Greenwood, 2013). Similarly, the secretion of enzymes, such as phosphatases, able to degrade organic compounds that chelate cations can increase their phytoavailability and acquisition by crops (White and Broadley, 2009; White and Greenwood, 2013). Associations with mycorrhizal fungi, and the cultivation of microbes that increase the phytoavailability of these elements in the rhizosphere are also beneficial (Barea et al., 2005; White and Broadley, 2009; White and Greenwood, 2013). The diffusion of these elements in the rhizosphere to the root surface can be accelerated by increasing the capacity for their uptake by root cells, either as cations or as phytosiderophore complexes (White and Broadley, 2009; White and Greenwood, 2013). Increasing $\mathrm{Fe}(\mathrm{III})$ reductase activity in the rhizosphere increases Fe acquisition (White and Broadley, 2009) and the presence 
of microbes oxidizing $\mathrm{Mn}$ to $\mathrm{Mn}^{2+}$ increases $\mathrm{Mn}$ acquisition (Nogueira et al., 2007).

\section{CONCLUSIONS}

Although the efficient acquisition of a particular mineral element requires a specific set of root traits, suites of traits can be identified that benefit the acquisition of groups of mineral elements (Figure 1B). Elements can be divided into three groups. The elements in Group 1 are nutrients that are often deficient in low-input agriculture. Group 1A comprises N, S, K, and B, whose inorganic forms are readily soluble in the soil solution and large amounts of which reach the root surface by mass flow. Group 1B includes only $\mathrm{P}$, which reaches the root surface primarily by diffusion. The elements in Group 2 are the micronutrients $\mathrm{Fe}, \mathrm{Zn}, \mathrm{Cu}$, $\mathrm{Mn}$, and $\mathrm{Ni}$ that are often present in adequate amounts in soils, but whose phytoavailability is restricted in alkaline soils.

Several root traits will improve the acquisition of mineral elements generally (Figure 1). Breeding for crops with improved resource acquisition might target these traits for maximum effect. These traits include early root vigor and greater biomass allocation to roots, architectural traits that increase root exploration of the soil, and anatomical traits that reduce the respiratory burden. Mycorrhizal associations and resistance to root pathogens also appear to benefit the acquisition of most essential mineral elements. Increasing transpiration will improve the acquisition of all elements delivered to the root surface primarily by mass flow of the soil solution. The acquisition of a smaller set of elements is

\section{REFERENCES}

Barber, S. A. (1995). Soil Nutrient Bioavailability: A Mechanistic Approach. 2nd Edn. New York, NY: Wiley.

Barea, J. M., Pozo, M. J., Azcón, R., and Azcón-Aguilar, C. (2005). Microbial co-operation in the rhizosphere. J. Exp. Bot. 56, 1761-1778. doi: 10.1093/jxb/eri197

Bennett, A. E., Daniell, T. J., and White, P. J. (2013). "Benefits of breeding crops for yield response to soil organisms," in Molecular Microbial Ecology of the Rhizosphere, ed F. J. de Bruijn (Hoboken, NJ: WileyBlackwell), 17-27.

Brown, P. H., and Bassil, E. (2011). "Overview of the acquisition and utilization of boron, chlorine, copper, manganese, molybdenum, and nickel by plants and prospects for improvement of micronutrient use efficiency," in The Molecular and Physiological Basis of Nutrient Use Efficiency in Crops, eds M. J. Hawkesford and P. Barraclough (Chichester: John Wiley and Sons), 377-428. doi: 10.1002/9780470960707.ch17

Brown, L. K., George, T. S., Dupuy, L., and White, P. J. (in press). A conceptual model of root hair ideotypes for future agricultural environments: what combination of traits should be targeted to cope with limited P availability? Ann. Bot. doi: 10.1093/aob/mcs231

Canfield, D. E., and Farquhar, J. (2012). "The global sulfur cycle," in Fundamentals of Geobiology, eds A. H. Knoll, D. E. Canfield, and K. O. Konhauser (Chichester: John Wiley and Sons), 49-64. doi: 10.1002/ 9781118280874.ch5

Chapin, F. S., Matson, P. A., and Mooney, H. A. (2002). Principles of Terrestrial Ecosystem Ecology. New York, NY: Springer Verlag.

De Kok, L. J., Stulen, I., and Hawkesford, M. J. (2011). "Sulfur nutrition in crop plants," in The Molecular and Physiological Basis of Nutrient Use Efficiency in Crops, eds M. J. Hawkesford and P. Barraclough (Chichester: John Wiley and Sons), 295-309. doi: 10.1002/9780470960707.ch14

Dunbabin, V., Diggle, A., and Rengel, Z. (2003). Is there any optimal root architecture for nitrate capture in leaching environments? Plant Cell Environ. 26, 835-844. doi: 10.1046/j.1365-3040.2003.01015.x

Fageria, N. K., Baligar, V. C., and Jones, C. A. (2011). Growth and Mineral Nutrition of Field Crops. Boca Raton, FL: CRC Press.

targeted by breeding for root proliferation in the topsoil (P, Mn, $\mathrm{Cu}$, and $\mathrm{Ni}$ ) or at depth $(\mathrm{N}, \mathrm{S}, \mathrm{K}$, and $\mathrm{B})$. Breeding for root proliferation in patches of organic matter will also improve the acquisition of several elements and benefits from the secretion of enzymes that degrade organic compounds into these areas. The secretion of mucilage, organic acids, and phytosiderophores will also improve the acquisition of several mineral elements. By contrast, breeding for root traits that increase the acquisition of either a single or a limited number of element(s) will have utility only in environments in which agricultural production is restricted by lack of a single or few key elements. Such traits include root proliferation in patches of soil with high phytoavailability of a specific element, increasing the phytoavailability of a single element either through the release of specific exudates or by culturing a microbial population with an exclusive function, and increasing the root uptake capacity for a single element.

We believe that a rational way to apportion resources for harnessing root traits for sustainable agriculture is to prioritize traits benefitting the acquisition of several essential mineral elements and pay less attention to those benefitting the acquisition of only one. In this manner root ideotypes for multiple environments can be produced.

\section{ACKNOWLEDGMENTS}

This work was supported by the Rural and Environment Science and Analytical Services Division (RESAS) of the Scottish Government through Workpackage 3.3 (2011-2016).

Fitter, A. H., and Moyersoen, B. (1996). Evolutionary trends in root-microbe symbioses. Philos. Trans. R. Soc. Lond. B Biol. Sci. 351, 1367-1375. doi: 10.1098/rstb.1996.0120

Garnett, T., Conn, V., and Kaiser, B. N. (2009). Root based approaches to improving nitrogen use efficiency in plants. Plant Cell Environ. 32, 1272-1283. doi: $10.1111 /$ j.13653040.2009.02011.x

Gojon, A., Nacry, P., and Davidian, J.C. (2009). Root uptake regulation: a central process for NPS homeostasis in plants. Curr. Opin. Plant Biol. 12, 328-338. doi: 10.1016/j.pbi.2009. 04.015

Hawkesford, M. J. (2011). "An overview of nutrient use efficiency and strategies for crop improvement," in The Molecular and Physiological Basis of Nutrient Use Efficiency in Crops, eds M. J. Hawkesford and P. Barraclough (Chichester: John Wiley and Sons), 5-19. doi: 10.1002/9780470960707

James, E. K., and Baldani, J. I. (2012). The role of biological nitrogen fixation by non-legumes in the sustainable production of food and biofuels. Plant Soil 356, 1-3. doi: 10.1007/s11104-0121317-1
Jungk, A., and Claassen, N. (1997). Ion diffusion in the soil-root system. Adv. Agron. 61, 53-110. doi: 10.1016/S0065-2113(08)60662-8

Kraiser, T., Gras, D. E., Gutiérrez, A. G., González, B., and Gutiérrez, R. A. (2011). A holistic view of nitrogen acquisition in plants. J. Exp. Bot. 62, 1455-1466. doi: 10.1093/jxb/erq425

Kumar, J., Pratap, A., Solanki, R. K., Gupta, D. S., Goyal, A., Chaturvedi, S. K., et al. (2012). Genomic resources for improving food legume crops. J. Agric. Sci. 150, 289-318. doi: 10.1017/S0021859611000554

Lamers, L. P. M., van Diggelen, J. M. H., Op den Camp, H. J. M., Visser, E. J. W., Lucassen, E. C. H. E. T., Vile, M. A., et al. (2012). Microbial transformations of nitrogen, sulfur, and iron dictate vegetation composition in wetlands: a review. Front. Microbiol. 3:156. doi: 10.3389/fmicb.2012.00156

López-Bucio, J., Cruz-Ramírez, A., and Herrera-Estrella, L. (2003). The role of nutrient availability in regulating root architecture. Curr. Opin. Plant Biol. 6, 280-287. doi 10.1016/S1369-5266(03)00035-9

Lynch, J. P. (2007). Roots of the second green revolution. Aust. J. Bot. 55, 493-512. doi: 10.1071/BT06118 
Lynch, J. P. (2011). Root phenes for enhanced soil exploration and phosphorus acquisition: tools for future crops. Plant Physiol. 156, 1041-1049. doi: 10.1104/pp.111.175414

Lynch, J. P. (in press). Steep, cheap, and deep: a hypothetical ideotype to optimize water and $\mathrm{N}$ acquisition by maize root systems. Ann. Bot. doi: $10.1093 / \mathrm{aob} / \mathrm{mcs} 293$

Marschner, P., and Rengel, Z. (2012). "Nutrient availability in soils," in Marschner's Mineral Nutrition of Higher Plants, ed P. Marschner (Amsterdam: Elsevier), 315-330. doi: $\quad$ 10.1016/B978-0-12-3849052.00012-1

Miller, A. J., and Cramer, M. D. (2005). Root nitrogen acquisition and assimilation. Plant Soil 274, 1-36. doi: 10.1007/s11104-004-0965-1

Moradi, A. B., Oswald, S. E., Nordmeyer-Massner, J. A., Pruessmann, K. P., Robinson, B. H., and Schulin, R. (2010). Analysis of nickel concentration profiles around the roots of the hyperaccumulator plant Berkheya coddii using MRI and numerical simulations. Plant Soil 328, 291-302. doi: 10.1007/s11104-009-0109-8

Mueller, N. D., Gerber, J. S., Johnston, M., Ray, D. K., Ramankutty, N., and Foley, J. A. (2012). Closing yield gaps through nutrient and water management. Nature 490, 254-257. doi: 10.1038/nature11420

Nogueira, M. A., Nehls, U., Hampp, R., Poralla, K., and Cardoso, E. J. B. N. (2007). Mycorrhiza and soil bacteria influence extractable iron and manganese in soil and uptake by soybean. Plant Soil 298, 273-284. doi: 10.1007/s11104-007-9379-1

Oliveira, E. M. M., Ruiz, H. A., Alvarez, V. H., Ferreira, P. A., Costa, F. O., and Almeida, I. C. C. (2010). Nutrient supply by mass flow and diffusion to maize plants in response to soil aggregate size and water potential. Rev. Bras. Ciênc. Solo 34, 317-327.

Postma, J., and Lynch, J. P. (2012). Complementarity in root architecture for nutrient uptake in ancient maize/bean and maize/bean/squash polycultures. Ann. Bot. 110, 521-534. doi: 10.1093/aob/mcs082

Rengel, Z., and Damon, P. M. (2008). Crops and genotypes differ in efficiency of potassium uptake and use. Physiol. Plant. 133, 624-636. doi: 10.1111/j.1399-3054. 2008.01079.x

Richardson, A. E., Lynch, J. P., Ryan, P. R., Delhaize, E., Smith, F. A., Smith, S. E., et al. (2011). Plant and microbial strategies to improve the phosphorus efficiency of agriculture. Plant Soil 349, 121-156. doi: 10.1007/s11104-0110950-4

Roose, T., and Fowler, A. C. (2004). A mathematical model for water and nutrient uptake by plant root systems. J. Theor. Biol. 228, 173-184. doi: 10.1016/j.jtbi.2003.12.013

Simpson, R. J., Oberson, A., Culvenor, R. A., Ryan, M. H., Veneklaas, E. J., Lambers, H., et al. (2011). Strategies and agronomic interventions to improve the phosphorus-use efficiency of farming systems. Plant Soil 349, 89-120. doi: 10.1007/s11104011-0880-1

Smith, S. E., and Read, D. J. (2008). Mycorrhizal Symbiosis. 3rd Edn. New York, NY: Academic Press.

Subbarao, G. V., Sahrawat, K. L., Nakahara, K., Rao, I. M., Ishitani, M., Hash, C. T., et al. (in press). A paradigm shift towards lownitrifying production systems: the role of biological nitrification inhibition (BNI). Ann. Bot. doi: $10.1093 / \mathrm{aob} / \mathrm{mcs} 230$

Sumner, M. E., and Noble, A. D. (2003). "Soil acidification: the world story," in Handbook of Soil Acidity, ed Z. Rengel (New York, NY: Marcel Dekker), 1-28. von Uexküll, H. R., and Mutert, E. (1995). Global extent, development and economic impact of acid soils. Plant Soil 171, 1-15. doi: 10.1007/BF00009558

White, P. J. (2013). Improving potassium acquisition and utilisation by crop plants. J. Plant Nutr. Soil Sci. 176, 305-316. doi: 10.1002/jpln. 201200121

White, P. J., and Broadley, M. R. (2001). Chloride in soils and its uptake and movement within the plant: a review. Ann. Bot. 88, 967-988. doi: 10.1006/anbo.2001. 1540

White, P. J., and Broadley, M. R. (2003). Calcium in plants. Ann. Bot. 92, 487-511. doi: 10.1093/aob/mcg164

White, P. J., and Broadley, M. R. (2009). Biofortification of crops with seven mineral elements often lacking in human diets - iron, zinc, copper, calcium, magnesium, selenium and iodine. New Phytol. 182, 49-84. doi: 10.1111/j.1469-8137. 2008.02738.x

White, P. J., and Broadley, M. R. (2011). Physiological limits to zinc biofortification of edible crops. Front.Plant Sci. 2:80. doi: 10.3389/fpls.2011.00080

White, P. J., and Brown, P. H. (2010). Plant nutrition for sustainable development and global health. Ann. Bot. 105, 1073-1080. doi 10.1093/aob/mcq085

White, P. J., and Greenwood, D. J. (2013). "Properties and management of cationic elements for crop growth," in Soil Conditions and Plant Growth, ed P. J. Gregory and S. Nortcliff (Oxford: Blackwell Publishing), 160-194.

White, P. J., and Hammond, J. P. (2008). "Phosphorus nutrition of terrestrial plants," in The Ecophysiology of Plant-Phosphorus Interactions, ed P. J. White and J.P. Hammond (Dordrecht: Springer),
51-81. doi: 10.1007/978-1-40208435-5_4

White, P. J., Broadley, M. R., Greenwood, D. J., and Hammond, J. P. (2005). Proceedings of The International Fertiliser Society 568. Genetic modifications to improve phosphorus acquisition by roots. York: International Fertiliser Society.

White, P. J., Broadley, M. R., and Gregory, P. J. (2012). Managing the nutrition of plants and people. Appl. Environ. Soil Sci. 2012:104826. doi: $10.1155 / 2012 / 104826$

White, P. J., George, T. S., Gregory, P. J., Bengough, A. G., Hallett, P. D., and McKenzie, B. M. (in press). Matching roots to their environment. Ann. Bot. doi: 10.1093/aob/ $\operatorname{mct} 123$

Conflict of Interest Statement: The authors declare that the research was conducted in the absence of any commercial or financial relationships that could be construed as a potential conflict of interest.

Received: 15 March 2013; paper pending published: 11 April 2013; accepted: 24 May 2013; published online: 11 June 2013.

Citation: White PJ, George TS, Dupuy LX, Karley AJ, Valentine TA, Wiesel L and Wishart J (2013) Root traits for infertile soils. Front. Plant Sci. 4:193. doi: 10.3389/fpls.2013.00193

This article was submitted to Frontiers in Functional Plant Ecology, a specialty of Frontiers in Plant Science.

Copyright (C) 2013 White, George, Dupuy, Karley, Valentine, Wiesel and Wishart. This is an open-access article distributed under the terms of the Creative Commons Attribution License, which permits use, distribution and reproduction in other forums, provided the original authors and source are credited and subject to any copyright notices concerning any third-party graphics etc. 